\title{
(RE)FRAMING STUDENT LOAN DEBT AS A COMMONS
}

\author{
VICTORIA J. HANEMAN*
}

I

INTRODUCTION

Satellite photos in 1974 illustrated for the public the reality of the "tragedy of the commons." In northern Africa, there was a grassy, fenced, private pasture centered in a fallow 390-mile desolate patch of earth that had been destroyed by overgrazing. ${ }^{2}$ The private pasture was subdivided into five sections and the owner rotated animals to a new section each year, allocating a four-year recovery period for each section so that grazing was managed sustainably. ${ }^{3}$ The lush and fecund private pasture was a small, green oasis surrounded by a dead, brown public pasture. The carrying capacity (or grazing capacity) of the public pasture had been exceeded, causing it to fall to ruin. ${ }^{4}$ The underlying economic dynamic of a common resource remains the same whether the framed example is a grazing pasture, a fresh water lake, or city public parking. ${ }^{5}$ With increased demand of a resource that is open-access comes the potential for overuse. ${ }^{6}$ When distribution

Copyright $(2) 2021$ by Victoria J. Haneman.

This Article is also available online at http://lcp.law.duke.edu/.

* Frank J. Kellegher Professor of Trusts \& Estates, Creighton University School of Law. Special thanks to Dr. John Linarelli (Touro) and Dr. Orkun Akseli (Durham) for organizing the Financial Inclusion, Access to Credit, and Sustainable Finance Symposium hosted by Durham University Law School, and also coordinating this symposium issue. My heartfelt gratitude to research assistant Thomas R. Norvell for his attention to detail and impressive editing skill.

1. See Garrett Hardin, The Tragedy of the Commons, 27 EKISTICS 168, 169 (1969) (describing the ruin of an open-access commons that is available for unfettered use by an entire community).

2. Garrett Hardin, Tragedy of the Commons, LIBR. OF ECON. \& LIBERTY, https://www.econlib.org/ library/Enc/TragedyoftheCommons.html[https://perma.cc/5XCV-Y5JT].

3. Id.

4. James C. Wood, Intergenerational Equity and Climate Change, 8 GEO. INT'L. L. REV. 293, 309 (1996) ("With no limits on use or mechanism for control, individuals have no incentive to restrain themselves, and eventually the situation becomes worse for everyone.").

5. Jonathan H. Adler, Property Rights and the Tragedy of the Commons, ATLANTIC (May 22, 2012), https://www.theatlantic.com/business/archive/2012/05/property-rights-and-the-tragedy-of-the-co mmons/257549/ [https://perma.cc/R8JM-3HF4].

6. Dr. Seuss's classic children's book "The Lorax" is a book about both capitalistic greed and the tragedy of the commons. See Ilya Somin, The Lorax and the Tragedy of the Commons, VOLOKH CONSPIRACY (Aug. 27, 2007), http://volokh.com/2007/08/27/the-lorax-and-the-tragedy-of-the-commons/ [https://perma.cc/TPZ7-RKY5].

The truffula trees grow in an unowned commons. (The Lorax may speak for the trees, but he does not own them.) The Once-ler has no incentive to conserve the truffula trees for, as he notes to himself, if he doesn't cut them down someone else will. He's responding to the incentives created by a lack of property rights in the trees, and the inevitable tragedy results. Had the 
systems fail, it is appropriate to consider whether some type of commons exists ${ }^{7}$ as precursor to any determination that prescriptive regulation of the distribution system, or "mutual coercion, mutually agreed upon," is now justified or necessary. ${ }^{8}$

The work of Nobel-prize winner Elinor Ostrom pushes back against the notion of tragedy in the management of a commons, rejecting the idea that people are unable to cooperate in ways that are sustainable. ${ }^{9}$ The term "common pool resource" (CPR) is defined by Ostrom as "a natural or man-made resource system that is sufficiently large as to make it costly (but not impossible) to exclude potential beneficiaries from obtaining benefits from its use." 10 Examples of traditionally recognized CPRs include breathable air, clean water, grazing systems, and urban commons. ${ }^{11}$ Interdisciplinary researchers are applying CPR analysis to previously unrecognized resources, including surfers' waves, public radio, public parking, and the Internet. The core issue is always one of resource allocation-existing patterns of use will lead to the ruin or exhaustion of the common pool resource (CPR), but no individual resource-user has an incentive to limit or relinquish use. And while there are institutional frameworks of regulation by which a CPR may be managed sustainably, the first step in the process is identifying that a CPR is at issue.

Access to student loans as a means of facilitating higher education has undoubtedly redefined the lives of millions of Americans who would otherwise be unable to afford the expense. In this sense, student loan debt has the potential to be a transformative and empowering resource. But the problems inherent to student loan indebtedness with the use of student loans are also well known. And to the extent that rapid increases in debt are a red flag of a marketplace potentially in trouble, ${ }^{12}$ there are reasons to be concerned about the use of

\footnotetext{
Once-ler owned the trees, his incentives would have been quite different-and he would likely have acted accordingly - even if he remained dismissive of the Lorax's environmental concerns.
} Id.

7. Hardin, supra note 1 .

8. Garrett Hardin, The Tragedy of the Commons, 162 SCI. MAG. 1243, 1247 (1968).

9. This interesting anthropological research explores community behaviors such as empathy, ritual, and sharing as paths to sustainable management of commons. See THE ANTHROPOLOGY OF SustainabiLity: BEYOND DEVElopMENT AND PROGRESS 1-34 (Marc Brightman \& Jerome Lewis eds., 2017). See generally ElinOR OSTROM, GOvERning THE COMMONS: THE EvOlution OF InSTITUTIONS FOR COLlECTIVE ACTION (1990); Charlotte Hess \& Elinor Ostrom, Ideas, Artifacts, and Facilities: Information as a Common-Pool Resource, 66 LAW \& CONTEMP. PROBS., Winter/Spring, 2003, at 111,127-28. This interesting anthropological research explores community behaviors such as empathy, ritual, and sharing as paths to sustainable management of commons. See THE ANTHROPOLOGY OF SUSTAINABILITY, supra.

10. ElinOR OSTROM, GOVERNING THE COMMONS: THE EVOLUTION OF INSTITUTIONS FOR COLLECTIVE ACTION 30 (1990).

11. Hess \& Ostrom, supra note 9, at 127-28.

12. Rana Foroohar, The U.S. College Debt Bubble Is Becoming Dangerous, Fin. TIMES (Apr. 9, 2017), https://www.ft.com/content/a272ee4c-1b83-11e7-bcac-6d03d067f81f [https://perma.cc/MPY7WSED]. 
student loans in the United States. ${ }^{13}$ Specifically, younger generations may be saddled with more debt than they can reasonably service with projected incomes and without unintended consequences. ${ }^{14}$

Although ensuring broad access to higher education receives bipartisan political support in the United States, the accompanying question of how to fund accessibility is politically divisive. The current system for financing higher education is a blend of high tuition, inadequate needs-based grants, and staggering levels of student loan borrowing. Nearly seventy percent of the college class of 2019 financed some or part of their educations with student loan indebtedness, graduating with an average debt of $\$ 29,900 .{ }^{15}$ As of June 2020, outstanding student loan indebtedness in the United States exceeds $\$ 1.67$ trillion $^{16}$ and it is projected to exceed $\$ 2$ trillion $^{17}$ by 2021 or 2022 (varying by source). ${ }^{18}$

The United States has determined that broad access to higher education is an important social policy, and a decision has been made to primarily lean upon student loan indebtedness to finance higher education. There is much to unpack with regard to this choice, including the sustainability of heavy reliance upon debt and the intergenerational equity of shifting debt from this generation to the next. This Article takes one step forward in addressing a gap in existing scholarship through the framing of the student loan debt pool as a CPR - contemplating the need for cooperative management and resource allocation to avoid the inevitable tragedy that accompanies overuse or exhaustion of a CPR. Sustainable management of a resource is a core objective in the CPR theoretical framework, and to the extent that our society exists as part of an intergenerational continuum where the future matters as much - if not more - than the present, it is imperative that higher education policy in the United States is shaped with an eye towards

13. James Surowiecki, Debt by Degrees, NEw YORKER (Nov. 14, 2011), https://www.new yorker.com/magazine/2011/11/21/debt-by-degrees [https://perma.cc/9ZEY-ED6N].

14. John F. Wasik, How much college debt is too much? Here's your answer, CBS NEWS (Aug. 15, 2016), https://www.cbsnews.com/news/how-much-college-debt-is-too-much-its-relative/ [https://perma. cc/474H-XL5L].

15. A Look at the Shocking Student Loan Debt Statistics for 2020, STUDENT LOAN HERO (Jan. 15, 2020), https://studentloanhero.com/student-loan-debt-statistics/ [https://perma.cc/N92R-6LV9].

16. Security Loans Owned and Securitized, Outstanding, FED. RsRV. BANK OF ST. LOUIS, https:// fred.stlouisfed.org/series/SLOAS [https://perma.cc/SJ2C-CCQL].

17. To put this in perspective, Canada overtook Russia as having the tenth largest economy in 2015 , and its GDP was \$1.6 trillion. Caleb Silver, Top 20 Economies in the World, INVESTOPEDIA (updated June 7, 2019), https://www.investopedia.com/insights/worlds-top-economies/ [https://perma.cc/55K5H5Q9].

18. See, e.g., John Aidan Byrne, US students may collectively owe $\$ 2$ in loans by 2021, N.Y. POST (Aug. 11, 2018), https://nypost.com/2018/08/11/us-students-may-collectively-owe-2t-in-loans-by-2021/ [https://perma.cc/Q7N8-CRW2]; Steven R. Strahler, The bigger gut-punch from college debt, CRAIN'S CHI. BUS. (Mar. 26, 2016), https://www.chicagobusiness.com/article/20160326/ISSUE01/303269996/ college-debt-is-curbing-consumer-spending-slowing-the-economy [https://perma.cc/KRR5-XQ6A]; Annie Nova, It Could Become Essier for People with Student Debt to File for Bankruptcy, CNBC (May 11, 2019), https://www.cnbc.com/2019/05/10/it-could-become-easier-for-student-loan-borrowers-to-filebankruptcy.html [https://perma.cc/6V9Q-TTGS]. 
future needs. Or to couch this in terms of a metaphor, a bill that is due today must not be ignored and shuffled off to be paid tomorrow.

II

\section{STUdent LoAn DeBt AS A COMMON POOL RESOURCE}

There has been a staggering increase in demand for a college degree, as evidenced by college enrollments that have surged thirty-seven percent between 2000 and $2010 .{ }^{19}$ This increase in enrollment has resulted in a commensurate increase in dollars borrowed by enrollees. ${ }^{20}$ That said, two potentially seismic shifts in higher education finance policy coalesced during this 2000 to 2011 timeframe: (a) states divested dramatically from higher education as a result of the 2008 recession, and (b) the government became the dominant student loan lender in 2010.

Federal government divestment from higher education has arguably been ongoing since the 1980s, when assistance for higher education seemed to normatively shift from providing grant-based aid to offering access to debt. ${ }^{21}$ State government divestment ${ }^{22}$ from higher education follows the same trend line ${ }^{23}$ though funding cuts accelerated dramatically as a result of the 2008

19. Undergraduate Enrollment, NAT. CTR. FOR EDUC. STATS. (May 2020), https://nces.ed.gov/ programs/coe/indicator_cha.asp [https://perma.cc/K7K8-33L8] (percentage is figured using total undergraduate enrollment).

20. Devin Fergus, My Students Pay Too Much For College. Blame Reagan, WASH. Post (Sept. 2, 2014), https://www.washingtonpost.com/posteverything/wp/2014/09/02/my-students-pay-too-much-forcollege-blame-reagan [https://perma.cc/FAD2-S7P8].

At my employer, Ohio State University, student loan debt reportedly rose 23 percent faster than the national average between 2010 and 2012. This is true at state schools across the country. Student debt has risen nationally, and the sharpest uptick occurred at public universities with the highest-paid presidents. From 2006 to 2012, for example, the "average student debt of graduates in the top 25 public universities with the highest executive pay increased 5 percentage points more or 13 percent faster than the national average," according to one recent report.

Id.

21. Id ("Reagan administration Education Secretary Terrel Bell would later write in his memoir that students needing aid were part of the problem, not very different from other "undeserving" Americans, no different than the "welfare queen," the out-of-work father drawing unemployment insurance, the poor families on Medicaid, the elderly in need of Medicare or even farmers relying on subsidies.").

22. See Noreen Ohlrich, The Sinking of Public Higher Ed and the Tragedy of the Commons, NONPROFIT Q. (Jan. 20, 2017), https://nonprofitquarterly.org/sinking-public-higher-ed-tragedycommons/ [https://perma.cc/UN2M-VMRQ] ("Public universities have become national resources, not merely state resources, providing benefits both in the state and outside of it. ... Thus, federal support for public universities has grown in recent years because the scale of federal decision making and investment matches the national scale of usage of public universities. But meanwhile state support has fallen sharply because the scale of state decision-making and investment does not match the national scale of the hiring and mobility of the well-educated.").

23. There are some who disagree that there has been a decline in state taxpayer support of higher education, including Andrew Gillen of the Texas Public Policy Foundation. See Andrew Gillen, The Myth of State Divestment in Higher Education, TEX. PUB. POL'Y FOUND. (Oct. 2019), https://files.texasp olicy.com/uploads/2019/10/21124414/Gillen-The-Myth-of-State-Disinvestment-in-Higher-Education.pdf [https://perma.cc/X8Y6-MYSA]. 
recession - state funding at the close of the 2018 academic year was more than $\$ 6.6$ billion less than it was in $2008 .{ }^{24}$ One study identifies forty-five of forty-nine states as spending less per student in 2018 than in $2008,{ }^{25}$ with nine states spending more than thirty percent less per student. ${ }^{26}$ State support of higher education is demonstrably elastic, and, if contending with revenue shortfalls, states are inclined to make deep cuts to higher education. ${ }^{27}$ For the first time in history, public colleges and universities in most states now receive a majority of funding through tuition $^{28}$ rather than government appropriations. ${ }^{29}$

The second significant recent policy shift in higher education financing occurred in 2010 when the Obama Administration eliminated the forty-five-yearold federal guaranteed loan program that enabled private lenders to offer student loans at low interest rates. ${ }^{30}$ This revamping of higher education finance occurred as part of the healthcare package colloquially referred to as Obamacare $^{31}$ and received little public attention, likely because it was overshadowed by the political drama surrounding healthcare reform. ${ }^{32}$ Specifically, private banks were removed as middlemen in the student loan lending process and the system was

24. Michael Mitchell, Michael Leachman \& Matt Saenz, State Higher Education Funding Cuts Have Pushed Costs to Students, Worsened Inequality, CTR. ON BUDGET AND POL'Y PRIORITIES (Oct. 24, 2019), https:/www.cbpp.org/research/state-budget-and-tax/state-higher-education-funding-cuts-havepushed-costs-to-students [https://perma.cc/7WPR-TM26].

25. Bo Zhao, Consequences of State Disinvestment in Public Higher Education: Lessons for the New England States, FED. RSRV. BANK OF BOSTON (2019), https://www.bostonfed.org/publications/newengland-public-policy-center-research-report/2019/consequences-of-state-disinvestment-in-public-high er-education.asp [https://perma.cc/R9GY-GDDM] ("In 2017 in New England, real per-student state funding for higher education was lower than it was in 2008, with a double-digit decline in each of the region's states except Maine.").

26. Michael Mitchell, By Disinvesting in Higher Education, States Contributing to Affordability Crisis, CTR. ON BUDGET \& POL'Y PRIORITIES (Oct. 4, 2018), https://www.cbpp.org/blog/by-disinvestingin-higher-education-states-contributing-to-affordability-crisis [https://perma.cc/MD77-F2KS].

27. Id.

28. See Jeffrey J. Selingo, States' Decision to Reduce Support for Higher Education Comes at a Cost, WASH. POST (Sept. 8, 2018), https://www.washingtonpost.com/education/2018/09/08/states-decisionreduce-support-higher-education-comes-cost/ [https://perma.cc/2CJD-GR5W] ("At the beginning of last decade, college students who went to public universities paid for about one-third of their education. Today, in more than half the states, they pay for most of it").

29. See Ronald Brownstein, American Higher Education Hits a Dangerous Milestone, ATLANTIC (May 3, 2018), https://www.theatlantic.com/politics/archive/2018/05/american-higher-education-hits-adangerous-milestone/559457/ [https://perma.cc/TZ8L-WKYX].

In 1992, tuition accounted for slightly less than three-tenths of the total educational revenue for public colleges and universities. But by 2017, tuition supplied nearly half of the total revenue. In 28 states last year, tuition provided more revenue than public appropriations, SHEEO found. That was the first time a majority of states funded post-secondary education mostly through tuition.

Id.

30. William S. Howard, The Student Loan Crisis \& The Race to Princeton Law, 7 GEO. MASON J.L. ECON. \& POL'Y 485, 485 (2011).

31. David M. Herszenhorn \& Tamar Lewin, Student Loan Overhaul Approved by Congress, N.Y. TIMES (Mar. 25, 2010), https://www.nytimes.com/2010/03/26/us/politics/26loans.html [https://perma.cc/ MDE2-AEG7].

32. Id. 
recast as a system of direct-lending by the federal government. ${ }^{33}$ Whereas the federal government historically lent one-third of student loans through directlending programs ${ }^{34}$ this change resulted in the government lending one hundred percent of subsidized, government-guaranteed loans..$^{35}$ As of 2019, it is estimated that roughly ninety-two percent of total outstanding student loan debt consists of student loans owned by the U.S. Department of Education, with private student loan debt comprising about eight percent. ${ }^{36}$

As a result of these two important but seldom-discussed policy shifts, student loan indebtedness has increased dramatically under a student loan regime funded almost entirely by pooled government resources. These pooled government resources consist of resource units in the form of student loans ${ }^{37}$ that are individually owned by appropriators. ${ }^{38}$ And thus, higher education financing in the United States has arguably been recast as a CPR - though there is no question that this characterization will be disputed, as the term "commons" used to describe almost any system or resource tends to be disputed (often without resolution). ${ }^{39}$

CPRs arise in many different contexts, including local government, international government, and the private sector. ${ }^{40}$ Examples include the Internet, ${ }^{41}$ the atmosphere,${ }^{42}$ ancient relics ${ }^{43}$ clean water, ${ }^{44}$ government budgets,${ }^{45}$

33. Howard, supra note 30 , at 485.

34. Preston Cooper, Betsy DeVos Is Wrong About The 'Government Takeover' Of Student Loans, FORBES (Nov. 30, 2018), https://www.forbes.com/sites/prestoncooper2/2018/11/30/betsy-devos-is-wrongabout-the-government-takeover-of-student-loans/\#3daf59464990 [https://perma.cc/8WZF-88KM].

Nevertheless, the distinction between government and private loans can be less than clear. See id. ("Before 2010, most student loans were issued as guaranteed loans. Under this system, private banks lent money to students at terms the federal government dictated. The federal government then guaranteed banks' returns. If students failed to repay their loans, taxpayers picked up the bill. Congress even layered some extra subsidies on top to sweeten the deal for the lender ... [this system has been described as] "private in name only." Despite the presence of private lenders in the system, it operated according to the federal government's rules and on the federal government's dollar.")

35. Id.

36. Teddy Nykiel, 2019 Student Loan Debt Statistics, NerdWALLET (Dec. 20, 2019), https:// www.nerdwallet.com/blog/loans/student-loans/student-loan-debt/ [https://perma.cc/NW9Z-ZZ25].

37. Hess \& Ostrom, supra note 9 , at 121.

38. Id.

39. Id. at 115 .

40. Jonathan Rosenbloom, New Day at the Pool: State Preemption, Common Pool Resources, and Non-Place Based Municipal Collaborations, 36 HARV. ENVTL. L. REV. 445, 450 (2012).

41. Scott J. Shackelford, Governing the Internet of Everything, 37 CARDOZO ARTS \& ENT. L.J. 701, 705 (2019).

42. "The atmosphere is a global common-pool resource in its function as a sink for $\mathrm{CO} 2$ and other greenhouse gases." Ottmar Endenhofer, Christian Flachsland \& Bernhard Lorentz, The Atmosphere as a Global Commons, WEALTH OF THE COMMONS, http://wealthofthecommons.org/essay/atmosphereglobal-commons [https://perma.cc/DA3U-VJ7E].

43. Hess \& Ostrom, supra note 9, at 129-30.

44. Rosenbloom, supra note 40 , at 450.

45. Id. 
parking spaces ${ }^{46}$ city space ${ }^{47}$ and the African elephant. ${ }^{48}$ A commons is a resource that can be used by appropriators and may even grow and replenish itself but ultimately will be subject to collapse and ruin if overused. ${ }^{49}$ If overexploitation is managed, use can be sustained across generations or potentially indefinitely. CPR theory provides a framework for discussion: a way in which to define public goods and a starting point from which to call for cooperation with regard to management of the public good. ${ }^{50}$ Establishing rules (often fairly rigid rules) to manage a commons becomes necessary to fairly allocate resources and ensure sustainability. ${ }^{51}$

Two characteristics are the hallmarks of a public good for purposes of CPR theory: openness and subtractability. ${ }^{52}$ The former refers to the difficulty of excluding access to a resource, and the latter accounts for the fact that one user's appropriation may limit capacity or quality for another. ${ }^{53}$ The Federal student loan debt system is lauded for its openness ${ }^{54}$ and often critiqued because of subtractability. Limiting or excluding access to student loan debt means denying educational opportunities, and very few limitations upon borrowing have been put into place. ${ }^{55}$ One must be a citizen or eligible non-citizen, have a social security number, earn a high school diploma or its equivalent, enroll in an accredited educational institution, maintain a minimum 2.0 GPA, complete a Free Application for Federal Student Aid (FAFSA) Form, be in good standing

46. Paul Barter, A Rethinking of what Parking is in the First Place, REINVENTING PARKING (Jan. 26, 2012), https://www.reinventingparking.org/2012/01/rethinking-of-what-parking-is-in-first.html [https://perma.cc/8UJ7-PCLF].

47. "[T] he language of the 'commons' is being invoked to lay claim to, and protect against the threat of 'enclosure' by economic elites, a host of urban resources and goods which might otherwise be more widely shared by a broader class of city inhabitants." Sheila R. Foster \& Christian Laione, The City As A Commons, 34 YALE L. \& POL'Y REV. 281, 282 (2016).

48. Branden D. Jung, The Tragedy of the Elephants, 2017 WIS. L. REV. 695, 697 (2017) (arguing, in an effort to protect the few remaining elephants, that the African elephant is and has been an openaccess, common pool resource).

49. OSTROM, supra note 10, at 2-3, 15-21, 30-31.

50. J. Samuel Barkin \& Yuliya Rashchupkina, Public Goods, Common Pool Resources, and International Law, 111 AM. J. INT'L L. 376, 376 (2017).

51. Christopher W. Savage, Managing the Ambient Trust Commons: The Economics of Online Consumer Information Privacy, 22 STAN. TECH. L. REV. 95, 117 (2019).

52. Wood, supra note 4 , at 309.

53. Id.

54. Openness used here is meant to refer to non-excludability, and is not be be confused with openaccess in the context of a resource where no one may be legally excluded from use. There are, indeed, exclusions from use of the student loan debt pool in the United States. See Hess \& Ostrom, supra note 9, at 121.

55. "Stafford Loans are the most common financial aid available to students entering college and nearly every applicant is either eligible for either a subsidized or unsubsidized loan package." All About Stafford Loans, GOCOLLEGE.COM, http:/www.gocollege.com/financial-aid/student-loans/federal/ stafford-loans.html [https://perma.cc/PS2F-27MU]. See also The U.S. Department of Education offers low-interest loans to eligible students to help cover the cost of college or career school, STUDENTAID.GOV, https://studentaid.gov/understand-aid/types/loans/subsidized-unsubsidized\#eligibility [https://perma.cc/ ZY3G-XZB9] (noting that there is no requirement to show financial need to receive a direct unsubsidized loan). 
with other federal aid, and enroll as a part- or full-time student. ${ }^{56}$ In fact, the almost incomprehensible vastness of $\$ 1.6$ trillion in student loan debt supports the notion that the resource is characterized by its openness and accessibility ${ }^{57}$

A CPR differs from a public good in that the latter is non-subtractable meaning that consumption by one does not reduce available consumption for another. ${ }^{58}$ It is tempting to classify student loan debt as a public good rather than a CPR, but to do so would only be the result of an inability to quantify consumption capacity of the system-and to do so offers us the comfort of believing that the system is not finite and no crisis looms on the horizon. The extent to which the government can lean upon debt is indeed finite and is usually evidenced by a systemically unsustainable level of borrower defaults. The subtractability of the resource may well prove to be an omen ${ }^{59}$ of an impending crisis; no one (and most certainly not politicians) will agree upon the appropriation capacity of the student loan debt system until overexploitation has occurred and is evidenced in hindsight. ${ }^{60}$ Assuming that the pool of available funds from which to extend student loan debt is finite, a crisis of resource loss is inevitable when individual appropriators have no incentive to moderate, limit, or reduce usage - bringing to mind the tragedy of the commons. ${ }^{61}$

Many student borrowers-and, in some instances, borrowing parentsunderstand that current borrowing may eventually collapse and ruin the system, but no one borrower or appropriator has an incentive to reduce use..$^{62} \mathrm{~A}$ valuable resource that would inure to the benefit of successive generations may be

56. Zina Kumok, What are the Requirements to Get a Student Loan?, COLLEGE INV'R (Feb. 11, 2020), https://thecollegeinvestor.com/18701/requirements-get-student-loan/ [https://perma.cc/K3JE3W7Y].

57. The Bennet Hypothesis is a theory put forward by former Education Secretary William Bennett. Specifically, it proposes that "increases in financial aid in recent years [have] enabled colleges and universities blithely to raise their tuition, confident that Federal Loan Subsidiaries would help cushion the increase."' Josh Russell, Bennet Hypothesis: Does Student Aid Raise Tuition?, KaufFMAn Found. (Mar. 4, 2015), https://www.kauffman.org/currents/bennett-hypothesis-does-student-aid-raise-tuition/ [https://perma.cc/K9UC-H3MK] (citing William J. Bennett, Our Greedy Colleges, N.Y. TIMES (Feb. 18, 1987), https://www.nytimes.com/1987/02/18/opinion/our-greedy-colleges.html [https://perma.cc/772E$6 \mathrm{HVH}])$.

58. Inge Kaul, Donald Blondin \& Neva Nahtigal, Review Article: Understanding Global Public Goods: Where We Are and Where to Next, in GLOBAL PUBLIC Goods 4 (Inge Kaul ed., 2016).

59. There seems generally to be a concern about easy access to debt leading to its potential overuse and an eventual economic downturn. See, e.g., ANTONIO DOBLAS-MADRID \& KEVIN J. LANSING, FED. RES. BANK OF S.F., CREDIT-FuELled BUbBLES 1 (March 2016), https://www.frbsf.org/economicresearch/files/wp2016-02.pdf [https://perma.cc/3GR4-8V9S] ("In the context of recent housing busts in the United States and other countries, many observers have highlighted the role of credit and speculation in fueling unsustainable booms that lead to crises.").

60. D.V Budescu, Amnon Rapoport \& Ramzi Suleiman, Common Pool Resource Dilemmas under Uncertainty; Qualitative Tests of Equilibrium Solutions, 10 GAMES \& ECON. BEHAV. 171, 171-201 (1995).

61. Wood, supra note 4, at 309.

62. Howard Marks, You Can't Predict. You Can Prepare., OAK Tree CaP. MgmT. (Nov. 20, 2001), https://www.oaktreecapital.com/docs/default-source/memos/2010-12-01-open-and-shut.pdf [https:// perma.cc/QM8A-67Y8] ("[o]verpermissive providers of capital frequently aid and abet financial bubbles.... In the financial world, if you offer cheap money, they will borrow, buy and build - often without discipline, and with very negative consequences."). 
destroyed through overexploitation, and few conversations are happening concerning our legal or moral obligations to our future generations. ${ }^{63}$ By framing the student loan debt system as a CPR, and attaching this label to the resource, responsibilities of stewardship attach to and guide use. ${ }^{64}$

\section{III}

\section{REFRAMING THE NARRATIVE}

As scholars struggle with the almost incomprehensible balance of student loan debt outstanding in the United States, the conversation that needs to occur, but rarely does, concerns appropriation capacity of the resource. A goal of managing any commons is preventing the underlying resource from collapsing due to overuse. ${ }^{65}$ Most - though apparently not all-would agree that debt resources are finite, and rate of default will inherently constrain the system in its present form. To this end, it is significant that the student loan debt pool has been removed from the market and placed into the hands of the government. This is problematic for two reasons: first, historic market forces no longer operate; and second, it becomes particularly troublesome should the rate of default exceed the capacity of the system.

Student loan debt is a special type of indebtedness because it is subject to a system that has been removed from the normative lending marketplace. ${ }^{66}$ Loans are extended without regard to the creditworthiness of the borrower or the likelihood of repayment. It is the only type of debt that continued to rise through the Great Recession of $2007 .{ }^{67}$ The liquidity in the marketplace may be creating upward pressure on tuition but Congress seems committed to its politically popular path of supporting borrowing without caps or limits. ${ }^{68}$ Thus, the cycle continues and the upward pressure on tuition causes younger generations to borrow more, often without regard to whether the debt load can be reasonably serviced based upon projected income. ${ }^{69}$ Many of the basic protections afforded to other borrowers are unavailable in the context of student loan debt: no statutes

63. And certainly, this discussion of student loan debt as a CPR will be wholly meaningless to any reader who believes that unfettered consumption without regard to sustainability is his or her right.

64. Professor Jonathan Charney suggests that exceptional norms may be binding as universal law. Jonathan I. Charney, Universal International Law, 87 AM. J. INT’L L. 529, 529 (1993).

65. Savage, supra note 51, at 135 .

66. Federal guarantees eliminate lender risk. Because of this guarantee program, "[e]ducational institutions themselves [are] at least two steps away from the financial accountability for their graduate's outcomes .... [t] hanks to the moral hazard that the federally-backed loan program creates, some schools with the worst employment records for recent graduates have students with the highest levels of law school loan debt." Steven J. Harper, America's Student Loan System Has Created Perverse Incentives for Law Schools, BUS. INSIDER (Sept. 22, 2014), https:/www.businessinsider.com/student-loans-havecreated-a-moral-hazard-2014-9 [https://perma.cc/PWJ7-YX5L].

67. Lisa M. Barbacci \& Alanna S. Welling-Arnold, Student Loan Debt in Bankruptcy: A Trend Towards Dischargeability, 2014 ANN. SURV. BANKR. L. 12, 12 (2014).

68. Wasik, supra, note 15.

69. Id. 
of limitations apply, ${ }^{70}$ fair debt collection practices do not apply, ${ }^{71}$ and it is practically impossible to discharge the debt in bankruptcy. ${ }^{72}$

Further, the federal government plays an even more dominant role in higher education financing since 2010 as the direct lender of more than $90 \%$ of the student loan debt in the United States. ${ }^{73}$ The accelerated growth of both the outstanding debt load and the rate of default on repayment are issues that deserve attention. The meteoric growth of student loan debt places it second only to mortgage debt as a source of outstanding consumer debt in the United States. ${ }^{74}$ Assuming the same steady rate of growth over the next twenty years, the outstanding student loan balance will be $\$ 13.63$ trillion in $2039 .{ }^{75}$ In other words, growth of outstanding student loan debt at an average of $11 \%$ annually will far outstrip the $3.4 \%$ average annual growth of the Gross Domestic Product of the United States from 1948 to $2019 .{ }^{76}$

The vastness of these numbers should draw attention to the issue of borrower default on repayment. ${ }^{77}$ In 2017, a report released by the Department of Education tracking graduates' repayment over the course of twenty years applied their tracked data to the 2004 graduating cohort and predicted that as many as forty percent of borrowers will be in default by $2023 .^{78}$ This data did not account for an unpredictable surge in default rate if, by way of example, there were to be

70. It is necessary to distinguish between private and federal student loans on this point. Private student loans are subject to a statute of limitations. Federal student loan debt, which represents the lion's share of student loan debt in the United States, is not subject to a statute of limitations. Ryan Lane, Is There a Statute of Limitations on Student Loans?, NERDWALlET (Sept. 18, 2020), https://www.nerdwallet.com/article/loans/student-loans/statute-of-limitations-student-loans [https:// perma.cc/4R7V-JUE7].

71. Hector E. Lora, 9th Cir. Holds Student Loan Guaranty Agency Not Subject to FDCPA, MAURICE WuTSCHER: CONSUMER FIN. SERVS. BLOG (Feb. 13, 2020), https://consumerfsblog.com/2020/ 02/9th-cir-holds-student-loan-guaranty-agency-not-subject-to-fdcpa/ [https://perma.cc/A36C-2GBZ].

72. Alan Collinge, Opinion, Trump is pushing the student loan system to the brink of failure, BOSTON GLOBE (June 05, 2017), https:/www.bostonglobe.com/opinion/2017/06/05/trump-pushing-student-loansystem-brink-failure/qVdq1lhfc9mJwoaaZ1z1kM/story.html [https://perma.cc/TV85-A84C].

73. Susan Dynarski, BROOKINGs InST., AN ECONOMIST PERSPECTIVE ON STUDENT LOANS IN THE UNITED STATES 7 (Sept. 2014), https://www.brookings.edu/wp-content/uploads/2016/06/economist_ perspective_student_loans_dynarski.pdf [https://perma.cc/5PDC-VT63] ("Besides Stafford, most other loans are also federal; just 7 percent of student loan volume was from private sources in 2011-12.").

74. Student loans, after mortgages, are the largest source of household debt. Id at 1.

75. FED. RES. BANK OF N.Y., 2019 Q. REP. ON HOUSEHOLD DEBT \& CREDIT, https://www.new yorkfed.org/medialibrary/interactives/householdcredit/data/pdf/HHDC_2019Q1 [https://perma.cc/ NY8G-U6BU].

76. Id.

77. It is worth noting that the extraordinary complexity of a plethora of repayment plans and options does not assist with repayment. Both Republicans and Democrats have expressed interest in reducing the number of options from fourteen down to two. Annie Nova, Student loan borrowers could see big changes in 2020, CNBC (Dec. 6, 2019), https:/www.cnbc.com/2019/12/06/2020-could-be-the-yeareverything-changes-for-people-with-student-debt.html [https://perma.cc/RQS6-5YLM].

78. Judith Scott-Clayton, The looming student loan default crisis is worse than we thought, BROOKINGS INST. (Jan. 11, 2018), https://www.brookings.edu/research/the-looming-student-loandefault-crisis-is-worse-than-we-thought/ [https://perma.cc/M6FL-RS5A]. 
a pandemic coupled with a recession. ${ }^{79}$ In addition to the obvious impact upon the student loan program itself, the negative credit event of default has cascading consequences - potentially impacting homeownership, impeding formation of marriages, preventing the opening of small businesses, and delaying childbearing - all of which impact the economy. ${ }^{80}$

Hindsight will undoubtedly reveal whether we stand on or have fallen off the precipice of a debt crisis. ${ }^{81} \mathrm{We}$ have reason to be concerned, however, when many student loan borrowers find themselves temporarily helped rather than hurt by the COVID-19 pandemic because of the Coronavirus Aid, Relief, and Economic Security Act, which permits borrowers to forego payment until September $2020 .{ }^{82}$

The discussion above implicitly identified several ways in which the student loan debt commons may be cooperatively managed with the goal of sustainability. When one is faced with a CPR, the solutions for managing the resource are generally privatize the resource, ${ }^{83}$ unitize the resource (with a single operator), and or government regulation. ${ }^{84}$ Controlling against resource loss requires the imposition of some external authority, presumably resulting in development of prescriptions governing appropriation and optimizing use. To this end, the upside of the federal government directly managing the United States' debt-for-diploma system is that it arguably becomes easier to implement management tools that facilitate and ensure sustainability.

Our first step in that direction is understanding and embracing the need to reframe the conversation about student loan indebtedness in the United States. Controlling against resource loss through government regulation may become

79. Although the CARES Act was supposed to assist many borrowers through the pandemic and suspend payments through September 2020, many problems have arisen. See Adam S. Minkey, The Cares Act Was Supposed to Help Student Loan Borrowers, But For Many, It Has Failed, ForBes (June 8, 2020), https:/www.forbes.com/sites/adamminsky/2020/06/08/the-cares-act-was-supposed-to-help-student-loanborrowers-but-for-many-it-has-failed/ [https://perma.cc/2DMT-GA54]; see also Jennifer Barrett, Another Stimulus Bill May Be Coming This Summer: Here's What It Could Contain, FoRBES (June 13, 2020, 12:09 AM), https://www.forbes.com/sites/jenniferbarrett/2020/06/13/another-stimulus-bill-may-becoming-this-summer-heres-what-it-could-contain/ [https://perma.cc/55QR-SNC5] (noting, "many experts have warned that student loan delinquencies and defaults will rise if borrowers have to resume payments in October, when the extension exacted by the CARES Act expires").

80. Ari Rastegar, Student Loan Debt Holds Back Professionals And Market Growth, ForBES (June 4, 2020, 7:15 AM), https://www.forbes.com/sites/forbesrealestatecouncil/2020/06/04/student-loan-debtholds-back-professional-and-market-growth/ [https://perma.cc/WAP2-EUBY].

81. See Rachelle Hampton, Debt Nation: The faces and the lives behind America's student loan crisis, SLATE (July 16, 2020), https://slate.com/business/2020/07/debt-nation-the-faces-of-americas-studentloan-crisis.html [https://perma.cc/MJ39-DLTA] ("[O]ur collective student debt as a nation is currently at $\$ 1,740,184,278,148 \ldots$ The middle class . . . end up with more student loan debt on average than their peers from both higher and lower socioeconomic backgrounds.").

82. Id. Excusing payments until later in 2021 delays but does not solve the problem of surging rates of default.

83. See generally Lee Anne Fennell, Common Interest Tragedies, 98 Nw. U. L. REV. 907,926 (2004) (exploring the 'tragedy of the 'anticommons,' which can arise through assignment of legal rights over resources in response to the tragedy of the commons)

84. Barton H. Thompson, Tragically Difficult: The Obstacles to Governing the Commons, 30 ENVTL. L. 241, 243-244 (2000). 
slightly more realistic and politically feasible through the framework of cooperative and sustainable management of a CPR, specifically because sustainability often requires appropriators (and potential appropriators) to sacrifice or go without. ${ }^{85}$ Management of the student loan debt pool as a commons, which may be subject to ruin or exhaustion, has the potential to nudge $^{86}$ the interests of the individual into alignment with those of the larger group and create space for significant political change. ${ }^{87}$

\section{IV \\ CONCLUSION}

Framing the student loan debt pool as a commons renders tangible the idea that a nondeteriorated system of higher education financing should be handed to the next generations. Through this framework, the notion of intergenerational equity may be explored - if for no other reason than no one wishes to live in a world where each generation has the right to exhaust and collapse resources. ${ }^{88}$ Sustainable management of the student loan debt pool may require limits that constrain accessibility, and the decision to maintain broad accessibility would require a recommitment and reallocation of revenue. The CPR framework recognizes that many stakeholders have a claim to the resource, and collaborative governance tools may gain analytical traction in thinking through important resource allocation issues in order to avoid the inevitable "tragedy" that has been made real for us through metaphor. Crafting higher education finance policy in this type of intentional way would be a far better path than waiting for crisis or collapse. ${ }^{89}$ These conversations about the student loan industrial complex have always been timely, but even more so in the midst of a pandemic and recession. The COVID-19 pandemic is an existential global crisis highlighting the fact that debt is a useful tool to advance equality, but overreliance upon debt creates vulnerabilities.

85. See id at 256 (arguing that appropriators view access to a resource as a current right and sustainability is viewed by these appropriators as giving up or losing that right, while instead sustainability should be framed as a choice between a sacrifice and a complete loss).

86. See generally Richard H. THALER \& CASS R. SunSTEIN, Nudge: IMPROVING DECISIONS About HeAlth, WEALTh, AND Happiness (2009).

87. Irma S. Russell, A Common Tragedy: The Breach of Promises to Benefit the Public Commons and the Enforceability Problem, 11 TEX. WESLEYAN L. REV. 557, 562 (2005)("[T]he utility of the gain from use is individual while the loss (negative utility) incident to overuse and depletion of the commons is fractional.").

88. Voters can be disturbingly myopic - failing to understand that borrowing a large amount of public debt today will result in higher taxes and/or inflation tomorrow. Martin Frochmann et al., The Two Sides of Public Debt: Intergenerational Altruism and Burden Shifting, Plos OnE (Aug. 28, 2018), https://journals.plos.org/plosone/article?id=10.1371/journal.pone.0202963 [https://perma.cc/E5ZZ6TGM].

89. "No other investment yields as great a return as the investment in education. An educated workforce is the foundation of every community and the future of every economy." Brad Henry, Governor Brad Henry State of State - Transcript, VOTESMART (Feb. 7, 2005), https://votesmart.org/ public-statement/77474/governor-brad-henry-state-of-state-2005-transcript\#.XOGjP9NKgb0 [https:// perma.cc/F6FY-UG85]. 